\title{
Exploring the relationship between students' inclination to sports and their entrepreneurial intentions
}

\author{
Dr S. Pavan Kumar \\ Associate Professor \& Head, School of Management, \\ National Institute of Technology Karnataka (NITK), Surathkal \\ pavankumar@nitk.ac.in
}

\begin{abstract}
It is logical to explore the university students' inclination to sports and its impact on their entrepreneurial intentions, as both sports and entrepreneurship share many similar characteristics. In the last one-decade, scholars in the area of entrepreneurship were trying to find out the factors that can predict the entrepreneurial intentions among the students of higher education. This interest is largely because entrepreneurship has an important role to play in this competitive global business environment. It develops market economy. Thus, the topic of entrepreneurship has created motivation among the research scholars to find its antecedents. To achieve this aim, data were collected from 255 students who are studying an undergraduate course in Indian Universities. The proposed causal relationship in the model were examined with the help SmartPLS 3.0 software. The research showed interesting patterns; the students who want to be better than others in sport, and strive hard to become the best in sports have demonstrated their readiness for entrepreneurship intent. Further, the result shows that entrepreneurial attitude acts as a mediator between students' inclination to sports and entrepreneurial intention. Findings emphasize the importance of motivating students to participate in sports activities, not just for upkeeping their mental and physical health, but they are the people who can start their own enterprise. They are the people who can contribute to the growth of the economy. Administrators and the people who are at the helm of responsibility of educational institutions should endorse the fact and make efforts to provide all the required facilities for the young students to participate in sports.
\end{abstract}

Keywords: Sports, entrepreneurial intentions, educational institutions, and undergraduate students

\section{Introduction}

The motivation behind to explore the relationship between students' inclination to sports and their entrepreneurial intentions stems out of the common characteristics they possess. Sports and entrepreneurship can be linked form both the contextual and the individual perspective (Steinbrink, Berger, \& Kuckertz, 2020). Passion, vision, self-confidence, tenacity, flexibility and challenge seeking are seen as common characteristics between an entrepreneur and a sports person, though they are applied in different ways in both the domains. According to Steinbrink et al., (2020) people who are considering entrepreneurship as career option and those who undertake physical activity share certain personality traits. They are found to be emotionally stable, have a greater propensity for risk, and more conscientious (Hao Zhao, Seibert, \& Lumpkin, 2010). In addition, entrepreneurship is about individuals interacting with his/her environment to exploit opportunities that exist (Heinonen \& Poikkijoki, 2006), it holds true with sports as well. In the last one-decade scholars' in the area of entrepreneurship were trying to find the factors that can predict the entrepreneurial intentions among the students of higher education, as intentions have proven to be the best predictor of planned behavior (Krueger, Reilly, \& Carsrud, 2000). Previously, studies have examined the relationship between emotional intelligence, entrepreneurial self-efficacy, risk-taking propensity and entrepreneurial intention (Tiwari, Bhat, \& Tikoria, 2017; Timuroğlu \& Akpınar, 2017; Zhao, Seibert, $\&$ Hills, 2005). However, there exists a void in literature that explored the relationship between students' inclination towards sports and their entrepreneurial intentions. The premise to examine such a relationship is the study conducted by Feder \& Niţu-Antonie (2017), who concluded that attitude, subjective norm and perceived behavioral control are an essential indicators of entrepreneurial intention. Attitudes are part of individuals' personality and hence the relationship between students' inclination to sports and their entrepreneurial intentions needs an attention. Research in this domain has recognized theoretical relationship between top sports persons traits and personality traits of entrepreneurs; however, there exist no empirical research till date (Steinbrink et al., 2020).

There is another school of thought, which emphasizes on person-job-fit theory. Which says that people and their jobs are compatible when a job's demands and the persons' abilities, fit the individual's needs (Kristof, 1996). According to person-job-fit theory, assuming a person with sports inclination would likely to start his/her own enterprise is not an imaginary proposition. Ratten (2015) shows that the personality traits of athletes match with those of entrepreneurs. Linking sports and entrepreneurship is an emerging field of research (Hammerschmidt, Eggers, Kraus, Jones, \& Filser, 2020).

The manuscript is organized as follows: First, a review of literature, gaps in research and hypotheses are presented. Second, methodology section describes the sample and measures used. Third, reliability analysis and descriptive statistics are presented. Fourth, hypotheses testing is conducted using SmartPLS 3.0 and results are presented. Finally, discuss, implications and limitations of the study are presented.

\section{Review of Literature}

In the introduction part, we have seen that both sports person and the entrepreneur possess a common set of characteristics. To extent it further, 'need for achievement' is one another important characteristic that is common to 
both the sports person and the entrepreneur. Someone's attention to an achievement is termed as 'need for achievement'. It enables someone to perform better than other people or better than his/her previous achievement (McClelland, 1961). In sports, achievement goal theory is very popular and also well-researched theory in sport psychology (Nicholls, 1989). Achievement goal theory suggests that the ability is demonstrated by surpassing the performance of others, or by performing equally well when compared with others with less effort (Cumming, Smith, Smoll, Standage, \& Grossbard, 2008). Similarly, in the context of entrepreneurship, the need for achievement motivates someone to look for an entrepreneurial job to reach a higher achievement than another job (Kobia \& Sikalieh, 2010). In a recent research, it was found that need for achievement correlates to entrepreneurial intention (Suan, Ai, Raman, Loon \& Tanumihardja, 2011). In the present study need for achievement in sports is seen as inclination towards sports. Based on the above arguments, the following hypothesis is formulated.

\section{$\mathbf{H}_{\mathbf{1}}$ : There is a positive relationship between students, inclination towards sports and entrepreneurial intention}

One needs to possess specific characteristics to float a new enterprise in future or to develop an existing enterprise and take it to newer heights. Among many characteristics, need for achievement (Kobia \& Sikalieh, 2010) is a significant factor in motivating University students to prefer entrepreneurship as a career option. According to Luthje and Franke (2003) entrepreneur characteristics has a positive influence on entrepreneurial attitude. Thus, the need for achievement is one characteristic among the required entrepreneur characteristics, and it is expected to influence the entrepreneurial attitude. Thus, the following hypothesis has been developed.

\section{$\mathbf{H}_{2}$ : There is a positive relationship between students' inclination towards sports and entrepreneurial attitude}

According to Ajzen (1991, 2005), attitude refers to a tendency to which an individual like or dislike behavior in question, object, person or an event. Basically, an individual develops favorable or unfavorable attitude when they encounter with an object or event in question based on their own assessment. It is like, when an event is rated as good for me, one has a positive attitude and when the event is rated as bad for me, one has a negative attitude (Kusmintarti, Asdani, \& Riwajanti, 2017; Winkel, 2012). Sprouting an intention to have an entrepreneurial career is often seen as the first step in venture creation (Gartner, Shaver, Gatewood, \& Katz, 1994). Entrepreneurial intention talks about either creating a new business from start or developing an existing business (Bird, 1988). There exist several theories that predict entrepreneurial intention, to name a few, the maximization of expected utility model proposed by Douglas and Shepherd (2002), the model of implementing entrepreneurial idea (Bird, 1988) etc. However, theory of Planned Behavior (TPB) proposed by Ajzen (1991, 2005) has shown to predict entrepreneurial intention consistently (Moriano, Gorgievski, Laguna,
Stephan, \& Zarafshani, 2012). TPB suggests that intentions are determined by attitude towards the behavior. Entrepreneurial attitude can be understood as someone's tendency to like or dislike entrepreneurship. Luthje and Franke (2003) found that entrepreneurial attitude has positive and significant influence on entrepreneurial intention. It was also found that there is a dearth of research on entrepreneurial intentions in middle-income economies as classified by world bank (Iakovleva, Kolvereid, \& Stephan, 2011; Nabi \& Liñán, 2011). Based on the above literature, the following hypothesis is framed:

\section{H3: There is a positive relationship between entrepreneurial attitude and entrepreneurial intention among university students.}

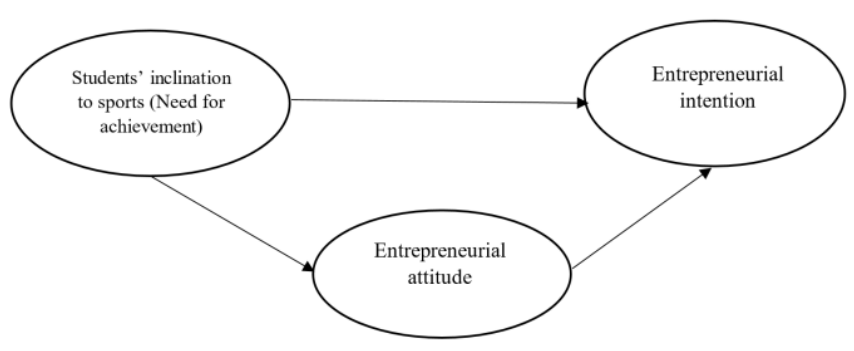

Figure1: Proposed Model

The above literature review suggests that there exists a positive relationship between need for achievement, entrepreneurial attitude, and entrepreneurial intention where need for achievement has a positive influence on both entrepreneurial attitude and entrepreneurial intention. In turn, entrepreneurial attitude influences entrepreneurial intention. Thus, the below mention mediation hypothesis is formulated.

\section{$\mathbf{H}_{4}$ : Entrepreneurial attitude act as mediator between students' inclination towards sports and entrepreneurial intention.}

\section{Method}

The study is based on a sample of 255 students pursuing undergraduate program in engineering from the institutions located in India. Judgement sampling method was adopted to collect the data. The median age of the respondents was 21 years. Students inclination towards sports was conceptualized as someone's need for achievement' in sports by demonstrating the ability to surpass the performance of others. It was measured by Achievement Goal scale for youth sports (Cumming et al., 2008). It has 12-items measuring two dimensions, six items measuring mastery and another six items measuring to ego involvement. For the present study, six items measuring ego was considered, as they were more suitable with the context of the study. Ego involved individuals strive to become the best sports person, who wins the most times in competing against others (Nicholls, 1984). Entrepreneurial attitudes was measured using five items which were adopted from 
Kickul and Krueger (2004), and Liñán and Chen (2009). Entrepreneurial intentions were measured using four items taken from Douglas and Fitzsimmons (2013). Response categories against each of the question for all the scales included in the study were on a seven-point Likert level. The proposed hypotheses were examined with SmartPLS 3.0 software.

\section{Results}

\section{A. Descriptive Statistics}

Table 1. Descriptive Statistics, Reliability coefficients, Correlations among latent variables, Average Variance Extracted (AVE). Diagonal values shown in italics are AVEs and Square root of AVE values are shown in parenthesis.

\begin{tabular}{cccccccc}
\hline Variable & Mean & SD & $\begin{array}{c}\text { Reliability } \\
\text { (Cronbach's } \\
\text { Alpha) }\end{array}$ & CR & SIS_NfA & Ent_Atribute & Ent_Intention \\
\hline SIS_NfA & 4.46 & 1.31 & 0.85 & 0.88 & $.57(.75)$ & & \\
Ent_Attribute & 5.88 & .98 & 0.86 & 0.90 & $.28^{* *}$ & $.65(.80)$ & \\
& & & & & & & \\
Ent_Intention & 5.71 & .99 & 0.76 & 0.84 & $.26^{* *}$ & $.71^{* *}$ & $.58(.76)$
\end{tabular}

Note: All correlations are significant at $* * p<.001$ level (2-tailed); SD Standard Deviation, CR - Composite Reliability, SIS NfA Students Inclination to Sports (Need for Achievement), Ent_Attribute - Entrepreneurial Attitude, Ent_Intention Entrepreneurial intention.

Reliability and validity should be tested to ensure proper psychometric properties of the scales (Kumar, 2020). As the values for Cronbach's alpha are well above the recommended threshold of .70 , the reliability of the measurements is considered to be acceptable (Fornell \& Larcker, 1981). Validity of the scale can be assessed by convergent and discriminant validity. In convergent validity indicators of a specific construct will converge towards a large portion of the variance that is in common. One way to verify this is to check AVE values greater than .5 (Hair et al., 1998). The AVE values are ranging from .57 to .65 for all the scales used in this study, they meet the criteria. Discriminant validity is said to be established when indicators within a construct are strongly associated with each other, but are different from other constructs indicators. To determine discriminant validity, square roots of AVEs should be higher than the correlations between the constructs. The square root of AVE values was ranging from .75 to .80 for all the scales used in this study, they were much higher than the correlations between the constructs. Hence, discriminant validity is also achieved (see table 1). Apart from the having proper validity and reliability, multicollinearity problem should be avoided. High collinearity between two or more indicators can seriously bias the results. Methodological research suggests Variance Inflation Factor (VIF) of 3.3 or less to avoid the issues of multi-collinearity (Kock \& Lynn, 2012). The VIF values for the present study were within the threshold limit of 3.3, and they were ranging from $1.30-3.3$.

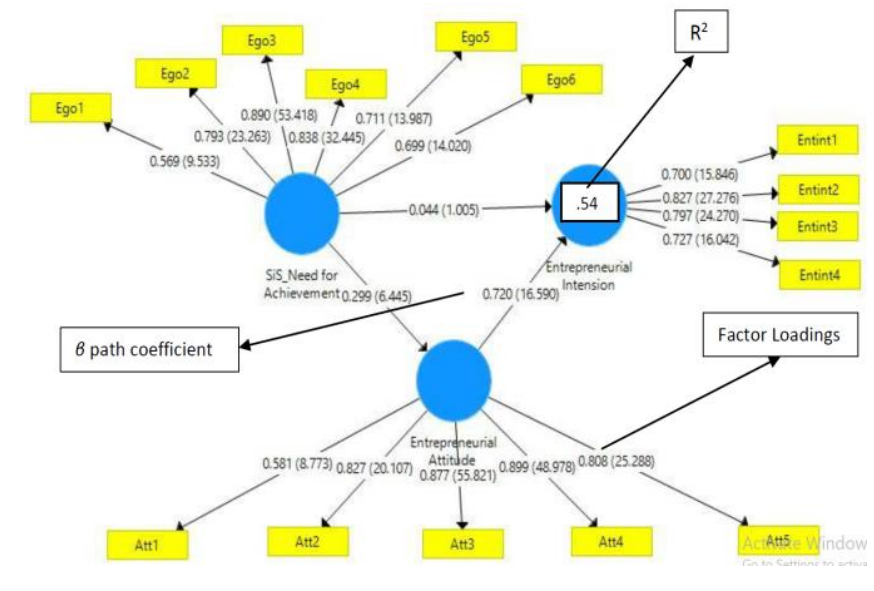

Figure 2: Entrepreneurial attitude as mediator between students' inclination to sports and entrepreneurial intention.

Figure 2 shows outer Loadings of Indicators, Inner values i.e., $\beta$ path coefficients, and $\mathrm{R}^{2}$ values. All the loadings are significant at $\mathrm{P}<.001, \beta$ path coefficient between students inclination to sports and entrepreneurial intention is nonsignificant at $\mathrm{p}<.001$. All the item loadings on their respective constructs were measured above .50 . and all were significant. t-statistics is shown in parenthesis for all the indicator variables and for the paths of the model. Any value for t-statistic above 1.96 is considered to be having significant level (Hair Jr, Hult, Ringle, \& Sarstedt, 2016).

Figure 3: Showing influence of students' inclination to sports on their

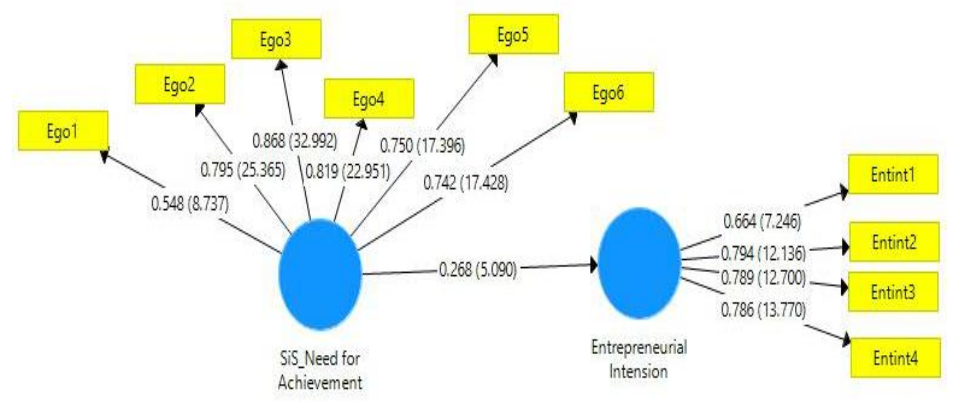

entrepreneurial intention

\section{Model Quality}

Model quality can be evaluated based on the ability of its exogenous constructs to predict the endogenous constructs. Coefficient of determination $\left(\mathrm{R}^{2}\right)$ is a measure of the model's predictive accuracy. For the proposed model, the $\mathrm{R}^{2}$ value is .54, which tells us that the exogenous constructs of the model have achieved moderate prediction accuracy. However, Hair Jr, Sarstedt, Hopkins, and G. Kuppelwieser (2014) suggests considering adjusted $R^{2}$, which penalises increasing model complexity by reducing the adjusted $\mathrm{R}^{2}$ when additional construct/(s) are added to the model. For the present proposed model, the adjusted $\mathrm{R}^{2}$ value is at .53 , which says that the exogenous constructs such as students' inclination to sports and students' entrepreneurial attitude of the model together explains 53 percentage of variance in students' entrepreneurial intention. The remaining 47 percentage is explained by other construct/(s) which is 
basically beyond the scope of the proposed model. Hence, the structural model is validated.

Figure 2 shows the results of $\beta$ coefficients for each link, and they represent the standardised regression path coefficients associated with statistically significant effects.

Table 2. Summary of hypothesised causal relationship and mediation results

\begin{tabular}{lllcc}
\hline S1. & Hypothesised & Path & t- & Result \\
No. & Relations & Coefficients & statistic &
\end{tabular}

$(\beta)$

\begin{tabular}{lllll}
\hline $\mathrm{H}_{1}$ & SIS_NfA $\rightarrow$ & $0.268^{* *}$ & 05.09 & Accepted \\
& Ent_Intention & & \\
$\mathrm{H}_{2}$ & SIS_NfA $\rightarrow$ & $0.30^{* *}$ & 06.50 & Accepted \\
& Ent_Attribute & & & \\
& & & & \\
$\mathrm{H}_{3}$ & Ent_Attribute $\rightarrow$ & $0.80^{* *}$ & 16.59 & Accepted \\
& Ent_Intention & & & \\
& & & & Accepted \\
$\mathrm{H}_{4}$ & SIS_NfA $\rightarrow$ & 0.04 & 01.05 & (Full \\
& Ent_Attribute $\rightarrow$ & & & Mediation) \\
& Ent_Intention & & &
\end{tabular}

Note: ** significant at $p<.001$, SIS_NfA - Students Inclination to Sports (Need for Achievement), Ent_Attribute - Entrepreneurial Attitude, Ent_Intention - Entrepreneurial intention.

See table 2, students' inclination to sports has a significant positive impact on students' entrepreneurial intention and students' entrepreneurial attitude with $(\beta=.268, \mathrm{p}<.001$, $\mathrm{t}=5.09)$ and $(\beta=.30, \mathrm{p}<.001, \mathrm{t}=6.50)$ respectively. Hence, both hypotheses $\mathrm{H}_{1}$ and $\mathrm{H}_{2}$ were accepted. Similarly, students' entrepreneurial attitude was having a significant positive impact on students' entrepreneurial intention with $(\beta=.80, \mathrm{p}<.001, \mathrm{t}=16.59)$; hence $\mathrm{H}_{3}$ is accepted. The result shows that the students' inclination to sports has a positive and significant influence with a beta coefficient of 0.268 on students' entrepreneurial intention, when the model is with no mediator, i.e., students' entrepreneurial attitude (see figure 3). However, upon introducing the mediator construct 'entrepreneurial attitude' in the model, the relationship between exogenous construct 'students' inclination to sports' and endogenous construct 'students' entrepreneurial intention' becomes insignificant and beta coefficient drops to 0.044, indicating a full mediation (Barron, \& Kenny, 1986). This essentially means the relationship between students' inclination to sports and students' entrepreneurial intention exists through the mediator construct students' entrepreneurial attitude. In other words, full mediation means, the influence of students' inclination to sports on students' entrepreneurial intention' is completely transmitted with the help of 'students' entrepreneurial attitude'. Hence, $\mathrm{H}_{4}$ is accepted.

\section{Discussion}

We have seen that there are many characteristics that are required to be demonstrated by both the sports person and the entrepreneur. The results have empirically shown that the one who is inclined to the sports are the one who is going to venture into entrepreneurship in the near future. The possible explanation for such a relationship is the commonality that exists between the sports person and the entrepreneur. Both of them have the propensity to take risk and attain desired goal. The findings of the present study reinforce the findings published by Bird (1988) and Mazzarol, Volery, Doss, and Thein (1999) which stated that the individual's personality could govern the entrepreneurial intention. The results also state that the person who has an urge to become best in sports among the competitors can have significant influence on entrepreneurial attitude. The explanation for such a relationship can be had from the point, the one who derives satisfaction being a good sports person also derives satisfaction on becoming a successful entrepreneur. Both of them find value in what they feel important for them to be. Previous studies such as Luthje and Franke (2003) identified the positive relationship between risk-taking propensity and entrepreneurial attitude.

Students' who possess an attitude of becoming owner of his/her own businesses tend to comprehend their entrepreneurial ideas in a couple of years down the lane. This finding is matching with Ajzen's theory (2005), which states that the attitude is the predictor of intention. To comprehend further, the present results are in line with the findings by Fini, Grimaldi, Marzocchi, and Sobrero (2009, 2012) which says that entrepreneurial attitude has positive influence on entrepreneurial intention.

The interesting part of the present study is to identify entrepreneurial attitude as a mediator between students' inclination to sports and their entrepreneurial intentions. It essentially means, the total influence of students' inclination to sports on entrepreneurial intentions is not just by itself, but it is explained through entrepreneurial attitude as well. Thus, we can say that students' entrepreneurial attitude acts as a mediator between students' inclination to sports on entrepreneurial intention.

The present research findings are important to the people who are at the helm of responsibility, who participate actively in decision-making process and also to the administrators of undergraduate programs. They need to ensure that adequate resources are made available to young students to actively participate in sports-related activities. Such participation will inculcate them to take challenges and still emerge as a winner, and it can make them realise how important it is to stay as a winner. All necessary steps should be taken to alter their attitude towards entrepreneurship as it plays a vital in propagating entrepreneurial intentions directly and also indirectly.

\section{Limitations}

The findings of this research paper have certain limitations. Firstly, the analysis was done on cross-sectional data, result may be better with longitudinal data analysis. Since the 
study used judgemental sampling method, generalisation of the findings may be considered with caution.

\section{Acknowledgements}

I sincerely thank Dr Suprabha K R, Dr Sambaji Rao and friends working for various universities for helping me in the data collection process.

\section{References}

Ajzen, I. (1991). The theory of planned behavior. Organisational Behavior and Human Decision Processes, 50(2), 179-211. https://doi.org/10.1016/07495978(91)90020-T

Ajzen, I. (2005). Attitudes, personality, and behavior. McGraw-Hill Education (UK).

Barron, R. M., \& Kenny, D. A. (1986). The mediatormoderator variable distinction in social psychological research: Conceptual, strategic, and statistical considerations. Journal of Personality and Social Psychology, 51(6), 1173-82.

Bird, B. (1988). Implementing Entrepreneurial Ideas: The Case for Intention. Academy of Management Review, 13(3), 442-453. https://doi.org/10.5465/amr.1988.4306970

Cumming, S. P., Smith, R. E., Smoll, F. L., Standage, M., \& Grossbard, J. R. (2008). Development and validation of the Achievement Goal Scale for Youth Sports. Psychology of Sport and Exercise, 9(5), 686-703. https://doi.org/10.1016/j.psychsport.2007.09.003

Douglas, E. J., \& Fitzsimmons, J. R. (2013). Intrapreneurial intentions versus entrepreneurial intentions: distinct constructs with different antecedents. Small Business Economics, 41(1), 115-132. https://doi.org/10.1007/s11187-012-9419-y

Douglas, E. J., \& Shepherd, D. A. (2002). Self-Employment as a Career Choice: Attitudes, Entrepreneurial Intentions, and Utility Maximization. Entrepreneurship Theory and Practice, 26(3), 81-90. https://doi.org/10.1177/104225870202600305

F. Hair Jr, J., Sarstedt, M., Hopkins, L., \& G. Kuppelwieser, V. (2014). Partial least squares structural equation modeling (PLS-SEM). European Business Review, 26(2), 106-121. https://doi.org/10.1108/EBR-10-2013-0128

Feder, E.-S., \& Niţu-Antonie, R.-D. (2017). Connecting gender identity, entrepreneurial training, role models and intentions. International Journal of Gender and Entrepreneurship, 9(1), 87-108. https://doi.org/10.1108/IJGE-08-2016-0028

Fini, R., Grimaldi, R., Marzocchi, G. L., \& Sobrero, M. (2009, June). The foundation of entrepreneurial intention. In Summer conference (Vol. 7, pp. 17-19).

Fini, R., Grimaldi, R., Marzocchi, G. L., \& Sobrero, M. (2012). The Determinants of Corporate Entrepreneurial Intention Within Small and Newly Established Firms. Entrepreneurship Theory and Practice, 36(2), 387-414. https://doi.org/10.1111/j.1540-6520.2010.00411.x

Fornell, C., \& Larcker, D. F. (1981). Evaluating Structural Equation Models with Unobservable Variables and Measurement Error. Journal of Marketing Research, 18(1), 39-50. https://doi.org/10.1177/002224378101800104

Gartner, W. B., Shaver, K. G., Gatewood, E., \& Katz, J. A.
(1994). Finding the Entrepreneur in Entrepreneurship. Entrepreneurship Theory and Practice, 18(3), 5-9. https://doi.org/10.1177/104225879401800301

Hair, J. F., Anderson, R. E., Tatham, R. L., \& William, C. Black (1998). Multivariate data analysis, 5, 87-135. Prentice Hall.

Hair Jr, J., Hult, G. T., Ringle, C., \& Sarstedt, M. (2016). A Primer on Partial Least Squares Structural Equation Modeling (PLS-SEM) - Joseph F. Hair, Jr., G. Tomas M. Hult, Christian Ringle, Marko Sarstedt. In Sage.

Hammerschmidt, J., Eggers, F., Kraus, S., Jones, P., \& Filser, M. (2020). Entrepreneurial orientation in sports entrepreneurship - a mixed methods analysis of professional soccer clubs in the German-speaking countries. International Entrepreneurship and Management Journal, 16(3), 839-857. https://doi.org/10.1007/s11365-01900594-5

Hao Zhao, Seibert, S. E., \& Lumpkin, G. T. (2010). The Relationship of Personality to Entrepreneurial Intentions and Performance: A Meta-Analytic Review. Journal of Management, 36(2), 381-404. https://doi.org/10.1177/0149206309335187

Heinonen, J., \& Poikkijoki, S. (2006). An entrepreneurialdirected approach to entrepreneurship education: mission impossible? Journal of Management Development, 25(1), 80-94. https://doi.org/10.1108/02621710610637981

Iakovleva, T., Kolvereid, L., \& Stephan, U. (2011). Entrepreneurial intentions in developing and developed countries. Education + Training, 53(5), 353-370. https://doi.org/10.1108/00400911111147686

Kobia, M., \& Sikalieh, D. (2010). Towards a search for the meaning of entrepreneurship. Journal of European Industrial Training, 34(2), 110-127. https://doi.org/10.1108/03090591011023970

Kock, N., \& Lynn, G. (2012). Lateral Collinearity and Misleading Results in Variance-Based SEM: An Illustration and Recommendations. Journal of the Association for Information Systems, 13(7), 546-580. https://doi.org/10.17705/1jais.00302

Kristof, A. L. (1996). Person-Organization Fit: An Integrative Review of its Conceptualisations, Measurement, and Implications. Personnel Psychology, 49(1), 1-49. https://doi.org/10.1111/j.1744-6570.1996.tb01790.x

Krueger, N. F., Reilly, M. D., \& Carsrud, A. L. (2000). Competing models of entrepreneurial intentions. Journal of Business Venturing, 15(5-6), 411-432. https://doi.org/10.1016/S0883-9026(98)00033-0

Kickul, J., \& Krueger, N. (2004). A cognitive processing model of entrepreneurial self-efficacy and intentionality. Frontiers of entrepreneurship research, 2004, 607-617.

Kumar, S. P. (2020). Workplace Spirituality as an Antecedent of University Teachers' Subjective Well-Being: Mediating Role of Job Satisfaction and Job Performance. Journal of Engineering Education Transformations, 33, 137-146.

Kusmintarti, A., Asdani, A., \& Riwajanti, N. I. (2017). The relationship between creativity, entrepreneurial attitude and 
entrepreneurial intention (case study on the students of State Polytechnic Malang). International Journal of Trade and Global Markets, $\quad$ 10(1), 28. https://doi.org/10.1504/IJTGM.2017.082379

Liñán, F., \& Chen, Y.-W. (2009). Development and CrossCultural Application of a Specific Instrument to Measure Entrepreneurial Intentions. Entrepreneurship Theory and Practice, 33(3), 593-617. https://doi.org/10.1111/j.15406520.2009.00318.x

Luthje, C., \& Franke, N. (2003). the "making" of an entrepreneur: testing a model of entrepreneurial intent among engineering students at MIT. $R$ and D Management, 33(2), 135-147. https://doi.org/10.1111/1467-9310.00288

Mazzarol, T., Volery, T., Doss, N., \& Thein, V. (1999). Factors influencing small business start-ups. International Journal of Entrepreneurial Behavior \& Research, 5(2), 4863. https://doi.org/10.1108/13552559910274499

McClelland, D. C. (1961). Achieving society (No. 15). Simon and Schuster.

Moriano, J. A., Gorgievski, M., Laguna, M., Stephan, U., \& Zarafshani, K. (2012). A Cross-Cultural Approach to Understanding Entrepreneurial Intention. Journal of Career Development, 39(2), 162-185. https://doi.org/10.1177/0894845310384481

Nabi, G., \& Liñán, F. (2011). Graduate entrepreneurship in the developing world: intentions, education and development. Education + Training, 53(5), 325-334. https://doi.org/10.1108/00400911111147668

Nicholls, J. G. (1984). Achievement motivation: Conceptions of ability, subjective experience, task choice, and performance. Psychological Review, 91(3), 328-346. https://doi.org/10.1037/0033-295X.91.3.328

Nicholls, J. G. (1989). The competitive ethos and democratic education. Harvard University Press.

Ratten, V. (2015). Athletes as entrepreneurs: the role of social capital and leadership ability. International Journal of Entrepreneurship and Small Business, 25(4), 442. https://doi.org/10.1504/IJESB.2015.070217

Steinbrink, K. M., Berger, E. S. C., \& Kuckertz, A. (2020). Top athletes' psychological characteristics and their potential for entrepreneurship. International Entrepreneurship and Management Journal, 16(3), 859878. https://doi.org/10.1007/s11365-019-00612-6

Suan, C. T., Ai, Y. J., Raman, K., Loon, K. W., \& Tanumihardja, J. (2011). Entrepreneurial intentions among university students. Business \& Management Quarterly Review, 2(3), 33- 38.

Timuroğlu, M. K., ve Akpunar, E. N. (2017). Duygusal Zekanın Girişimcilik Niyeti Üzerine Etkisi. Atatürk Üniversitesi İktisadi ve idari Bilimler Dergisi, 31(4), 875894.

Tiwari, P., Bhat, A. K., \& Tikoria, J. (2017). Predictors of social entrepreneurial intention: an empirical study. South Asian Journal of Business Studies, 6(1), 53-79. https://doi.org/10.1108/SAJBS-04-2016-0032

Winkel, W.S. (2012) Psikologi Pengajaran, Cetakan kelimabelas, Media Abadi, Yogyakarta.

Zhao, H., Seibert, S. E., \& Hills, G. E. (2005). The Mediating Role of Self-Efficacy in the Development of Entrepreneurial Intentions. Journal of Applied Psychology, 90(6), 1265-1272. https://doi.org/10.1037/0021-
9010.90 .6 .1265 


\begin{tabular}{|c|c|c|}
\hline SNo. & Item Code & Item Description \\
\hline 1 & Att1 & $\begin{array}{l}\text { Being an entrepreneur implies more } \\
\text { advantages than disadvantages for me }\end{array}$ \\
\hline 2 & Att2 & $\begin{array}{l}\text { Being an entrepreneur would give me } \\
\text { great satisfaction }\end{array}$ \\
\hline 3 & Att3 & $\begin{array}{l}\text { It is desirable for me to become an } \\
\text { entrepreneur }\end{array}$ \\
\hline 4 & Att4 & $\begin{array}{l}\text { It is intere sting for me to become an } \\
\text { entrepreneur }\end{array}$ \\
\hline 5 & Att5 & $\begin{array}{l}\text { It is attractive for me to become an } \\
\text { entrepreneur }\end{array}$ \\
\hline 6 & Entint1 & $\begin{array}{l}\text { How likely is it that you would want } \\
\text { to be self-employed within } 2 \text { years } \\
\text { after graduation, assuming you had a } \\
\text { good new business opporturity and } \\
\text { you could raise the funding necessary } \\
\text { to start your own business? }\end{array}$ \\
\hline 7 & Entint2 & $\begin{array}{l}\text { How likely is it that you would want } \\
\text { to be self-employed at some later point } \\
\text { in the future, assuming you had a good } \\
\text { opportunity and could raise the } \\
\text { funding necessary? }\end{array}$ \\
\hline 8 & Entint3 & $\begin{array}{l}\text { How likely is it that you would want } \\
\text { to start your own business to exploit a } \\
\text { radical innovation? }\end{array}$ \\
\hline 9 & Entint4 & $\begin{array}{l}\text { How likely is it that you would want } \\
\text { to start your own business to introduce } \\
\text { a new variant of an existing product or } \\
\text { service? }\end{array}$ \\
\hline 10 & Egol & $\begin{array}{l}\text { The most important thing is to be the } \\
\text { best athlete }\end{array}$ \\
\hline 11 & Ego2 & $\begin{array}{l}\text { My goal is to improve so I am better } \\
\text { than others }\end{array}$ \\
\hline 12 & Ego3 & $\begin{array}{l}\text { My goal is to be better than others in } \\
\text { my sport }\end{array}$ \\
\hline 13 & Ego4 & $\begin{array}{l}\text { I want to be better than others at my } \\
\text { sport }\end{array}$ \\
\hline 14 & Ego5 & $\begin{array}{l}\text { To me, success means being better } \\
\text { than others }\end{array}$ \\
\hline 15 & Ego6 & $\begin{array}{l}\text { I want to show that I am better than } \\
\text { others }\end{array}$ \\
\hline
\end{tabular}

